\title{
Atlantic Universities Geological Conference 1996
}

October 24-26, 1996

\author{
Abstracts \\ University of New Brunswick \\ Bailey Geological Society \\ Fredericton, New Brunswick
}

Again this year, abstracts from the annual Atlantic Universities Geological Conference (AUGC) are published in "Atlantic Geology". This provides a permanent record of the abstracts, and also focuses attention on the excellent quality of these presentations and the interesting and varied geoscience that they cover.

The Editors 


\title{
Fluid inclusions and microstructure of flexural-slip bedding-concordant veins within the Ovens Anticline, Lunenburg, Nova Scotia
}

\author{
Darcy Baker \\ Department of Earth Sciences, Dalhousie University, Halifax, Nova Scotia B3J 3J5, Canada
}

Fluid inclusions and microstructures of flexural-slip bedding-concordant quartz veins (FSBCVs) from the Ovens Anticline of the Meguma Group, were assessed and provide data on conditions and mechanisms of flexural-slip folding. These veins formed along flexural-slip movement horizons and are interpreted to have formed at the same time as flexural-slip folding.

Geobarometric results from planar fluid inclusion assemblages indicate that fluid pressure fluctuated and supralithostatic fluid pressures were present. Pressure results, when combined with an independent temperature of trapping (Tt), range from 0.5 to 5.0 kbars. The fluid was mixed $\mathrm{H}_{2} \mathrm{O}-\mathrm{NaCl}-\mathrm{CO}_{2}-\mathrm{CH}_{4}$ type.
FSBCVs contain abundant wall rock inclusion layers (WRIL) that originally were continuous but now are separated by layers of quartz. They host preferrentially oriented fluid inclusion planes (FIPs), and are composed of elongate quartz crystals which have a preferred crystallographic orientation with respect to elongation direction and possibly with respect to regional folding. FIP orientation appears to be crystallographically influenced. These data suggest that the FIPs measured may not be healed microfractures and their orientation is therefore not influenced by fold-related stress conditions.

\section{Fluid chemistry and hydrological regime of a fossil geothermal system in the Antigonish Highlands, Nova Scotia}

\author{
Tracy Cail \\ Department of Geology, St. Francis Xavier University, Antigonish, Nova Scotia B2G 1C0, Canada
}

\begin{abstract}
A series of hydrothermal veins, which can be traced intermittently over $10 \mathrm{~km}$ of coastal exposure in the northern Antigonish Highlands, Nova Scotia, were studied in order to identify the hydrologic controls and physico-chemical conditions of vein formation. The veins of interest consist mainly of calcite and minor amounts of euhedral quartz, sulphides and zeolites. In general, they occur within steeply dipping dextral faults that are parallel to the adjacent northeast trending Hollow fault.
\end{abstract}

The conditions of vein formation and the composition of the hydrothermal fluid were constrained using data obtained from hydrothermal minerals, alteration assemblages and fluid inclusion microthermometry. Microthermometric measurements of fluid inclusions in minerals from the vein and alteration assemblage were performed with a Linkham THMSG 600 heating and freezing stage. Petrographic and mineralogical analyses were done by transmitted and reflected light microscopy and powder X-ray diffraction techniques. Calcite crystals from open spaces within the veins contain two phase aqueous fluid inclusions of primary or psuedosecondary origin. Recorded eutectic temperatures indicate that the fluid inclusions can be modeled in the system $\mathrm{H}_{2} \mathrm{O}$ $\mathrm{CaCl}_{2}-\mathrm{NaCl}$. Freezing point depression yields bulk salinities between 25 and 30 wt. $\% \mathrm{NaCl}$ equivalency. $\mathrm{CO}_{2}$ clath- rate was not observed in the freezing measurements, however crushing techniques revealed small amounts of condensed gases, most probably $\mathrm{CO}_{2}$. Estimated trapping temperature for the inclusions range between 125 and $165^{\circ} \mathrm{C}$. These temperatures are consistent with the presence of analcite in the veins, and with propylitic alteration associated with an earlier vein set.

Analysis suggest that the veins are the product of a geothermal system formed by infiltration, heating and circulation of meteoric waters within an extensive permeable zone produced by the Hollow fault. The system was driven by heat supplied by deep circulation of fluids within the faults or by tectonic uplift of hot basement rocks. Interaction of fluids with evaporites and possibly connate brines within the early Carboniferous Windsor group sedimentary rock may account for the high salinity of the fluids. The absence of vapour-rich inclusions suggests that heating of the fluid, rather than phase separation, was largely responsible for precipitation of calcite. However, local concentrations of quartz and sulphides indicate that boiling occurred sporadically due to fluctuations in pressure or fluid salinity. A modern analogue of the studied system is the Salton Sea geothermal field, California. 


\title{
Large slump structures in the Macumber Formation, Basal Windsor Group, Ingonish area, northeastern Cape Breton
}

\author{
L.A. Cook \\ Department of Earth Sciences, Dalhousie University, Halifax, Nova Scotia B3H 3J5, Canada
}

The Macumber Formation outcrops as an almost horizontal sheet for $1100 \mathrm{~m}$ along the coast of Bear Cove, Victoria County. The formation consists of two lithologic zones, in upward succession: (1) carbonaceous, vuggy, black limestone $(0.5 \mathrm{~m})$; and (2) thinly to very thinly stratified, vuggy, peloidal dolomudstone (up to $18 \mathrm{~m}$ ). This second zone has laterally extensive, internally folded sheets arranged in stratigraphic sequence. Individual sheets intercalate either with undisturbed strata or with other deformed sheets. Folds in underlying sheets are unaffected by those in overlying sheets; the facing direction of folds differs between deformed sheets. The folds are tongue or tear-drop shaped, recumbent, isoclinal antiforms ranging in size from metres to several decametres. They form toe-like bodies with vertical separation surfaces; that is, synforms are absent. In plan sections, folds are fan shaped, with hinges curved through 180 degrees. Vergence varies: smaller folds face mainly east, larger ones are variable. The folding rotates lensoid vugs up to 20 $\mathrm{cm}$ in diameter. Smaller vugs only millimetres in diameter give a foamy appearance to volumes of the dolomudstone; other areas are a micro-breccia; macro-brecciation is absent, as is cleavage.

The fold forms are syndepositional slump structures. Bacterial $\mathrm{SO}_{2}$ reduction of organic matter in the basal carbonaceous limestone generated gas bubbles into wet mudstone of layer 2. Hydrodynamic shock probably due to earthquakes from boundary faults increased pore-fluid pressure. Liquefaction of the thixotropic carbonate ooze caused flowage across an essentially flat basin floor.

\section{Imaging of sedimentation and salt tectonics in an active convergent margin: eastern Mediterranean}

\section{Janis Drover \\ Department of Earth Sciences, Memorial University of Newfoundland, St. John's, Newfoundland A1B 3X5, Canada}

The Antalya Basin lies in the Eastern Mediterranean Sea, between the Turkish coast and the western edge of Cyprus. It is a fore-arc basin in an area of intense tectonic activity involving microplate convergence. Uplift associated with this convergence results in erosion of pre-existing rock in southern Turkey and deposition on the unstable continental shelf and slope. Sedimentation is disturbed by continuing regional tectonism that drives evaporite diapirism, and often results in collapse of sediments into the intervening deep water basin.

Acquisition of high resolution, 48 channel seismic reflection data by researchers at Memorial University of New- foundland has provided excellent images of the tectonic and sedimentary processes at work in this area of the eastern Mediterranean. Despite the high resolution of the data, the origin of some high relief structures remains questionable. More extensive and improved data processing is enhancing the imaging of these structures and our ability to map them along strike. The work of my Honors thesis will, therefore, involve processing additional seismic lines and improving migrations of previously processed lines, culminating in an enhanced interpretation of the regional geology of the Antalya Basin.

\section{Analytical electron microscopy of shock veins from the Catherwood L6 chondrite}

\author{
Karen Hendry \\ Department of Geology, University of New Brunswick, Fredericton, New Brunswick E3B 5A3, Canada
}

Shock veins are a very common feature of meteorites, especially stony meteorites. The commonly accepted theory for the formation shock veins is that they are caused exclusively by shock induced compression followed by a rapid decompression due to an impact generated shock wave passing through the target body. More recently, people have proposed that frictional heat also contributes to the formation of these veins. Evidence supporting this theory includes the displacement of grains along the veins and the melting and shearing of the metal and troilite phases due to their lower melting temperature.

The Catherwood L6 chondrite was analyzed using the petrographic microscope and the JEOL 6400 digital scanning electron microscope. Over twenty examples of shearing and displacement of grains were recognized, ranging from 6 to $550 \mu \mathrm{m}$ in offset. Grain displacement indicates there has been movement along the veins which would, in turn, produce heat. High pressure polymorphs of olivine (ringwoodite) and orthopyroxene (majorite) were identified in the veins, as well as the high pressure plagioclase polymorph maskelynite. This frictional movement, associated with shock pressure, is the most likely cause of the formation of shock veins. 


\title{
Neogene marine sediments of the Tanner Basin
}

\author{
Jennifer N. Henry \\ Department of Physics, Engineering and Geoscience, Mount Allison University, \\ Sackville, New Brunswick E0A 3C0, Canada
}

The Shipboard Scientific Party of Ocean Drilling Program Leg 167 drilled 13 sites along the climatically sensitive California Margin in the Pacific Ocean, arrayed in a series of depth and latitudinal transects to reconstruct the Neogene history of deep, intermediate and surface ocean circulation changes and to understand the paleoclimatic and geochemical history of this region. Leg 167 Sites 1010 through 1022 provided tremendous amounts of new data with bearing on paleoclimatic and paleoceanographic questions about the evolution of the California Current and the links between high and low latitudes from millennial and orbital to tectonic time scales.

The California Margin is an active tectonic regime and its morphology reflects this influence. This region is made up of a number of semi-enclosed tectonic basins marked by limited deep water exchange with the Pacific Ocean. The tectono-stratigraphic history of the California Margin can be accounted for by the intersection between the East Pacific Rise and the North American continent.

The Neogene basins along the California continental margin were formed by extension related to complex wrenchfault mechanisms. These extensional mechanisms caused the pull-apart tectonic that resulted in rapid deepening of many of the continental margin basins in the late Oligocene to early Miocene.

The slopes of the Margin are an important pathway for sediment transported from the mainland shelf, bank tops and island platforms to the adjacent basin floor. Sediment supply to the California Margin basins is highly seasonal, with the bulk of siliciclastic sedimentation derived from riverine runoff during winter and early spring rainstorms. Sedimentologic conditions on the slopes are governed by a complex interplay of depositional and mass-movement processes.

The water depth of Tanner Basin is $1177 \mathrm{~m}$ and the basin sill depth is $1165 \mathrm{~m}$. The age of the oldest sediment is late Miocene ( $5.0 \mathrm{Ma}$ ) and the linear sedimentation rate ranges from 27 to $214 \mathrm{~m}$ composite depth per million years.

The sedimentary sequence from the Tanner Basin consists of a well-dated apparently continuous $325 \mathrm{~m}$ thick interval of upper Pliocene to Quarternary sediments underlain by a relatively poorly dated $124 \mathrm{~m}$ thick sequence of early Pliocene to possible latest Miocene age. According to low $\mathrm{C} / \mathrm{N}$ ratios, the organic material is mainly marine in origin.
The partial isolation of the basins contribute to a severe reduction in oxygen concentrations in bottom waters from about $\sim 500$ to 600 million years ago, leading to the accumulation of organic carbon and anoxic muds. It is believed that more or less continuous mixing of basin waters with the overlying intermediate waters is the chief method of replenishment of the basin waters. Below sill depth, the modern basin contains oxygen depleted waters that derive from the upper part of the Pacific Intermediate Water mass and the Oxygen Minimum Zone (OMZ). Low oxygen concentrations in basinal bottom waters during the earliest Quaternary through the latest Pliocene coincided with strong upwelling conditons. During the Quaternary, benthic foraminifer assemblages change in association with glacial-interglacial oscillations, which suggest changes in upper intermediate water circulation during late Quaternary climatic cycles. Within the basin, this low-oxygen water mass is further depleted of oxygen by degradation of organic matter from the highly productive surface waters, rendering the seafloor inhospitable to benthic faunas and preventing bioturbation.

The data collected at the 4 Tanner Basin holes (Site 1014) have been used to sample a high-resolution section from the late Miocene to Quaternary to study the evolution of the California Current system and to study oceanographic processes in intermediate waters as northern hemisphere glaciations expanded. The study of the distribution of $\mathrm{Ca}$, $\mathrm{PO}_{4}$ and $\mathrm{Cd}$ as well as selected other trace elements in the Neogene sediments of the Tanner Basin helps elucidate possible mechanisms that help determine $\mathrm{Cd} / \mathrm{Ca}$ ratios in shells, seawater, sediments and ocean circulatory patterns. The geochemical behaviour of $\mathrm{Ca}, \mathrm{PO}_{4}$ and $\mathrm{Cd}$ stratigraphically and investigating the nature of phosphogenesis in the Neogene sedimentary record are being studied. It seems likely that in Neogene sediments, major reorganization of the joint oceanatmosphere system may have occurred in response to as yet poorly understood perturbation in the carbon cycle. This study will go a considerable way towards testing the extent to which the present $\mathrm{Cd}-\mathrm{PO}_{4}$ relationship and related distribution coefficients converting $\mathrm{Cd}-\mathrm{Ca}$ ratios into dissolved $\mathrm{Cd}$ and $\mathrm{PO}_{4}$ concentrations remains constant through geologic time. 


\title{
A detailed investigation of the morphological impact of in-stream remediation structures on Mill Brook, Kings County, Nova Scotia
}

\author{
Melody Myers \\ Department of Geology, Acadia University, Wolfville, Nova Scotia BOP IXO, Canada
}

In the summer of 1995, a hydrogeological study was conducted on Mill Brook, a tributary of the Cornwallis River. Mill Brook is about $10 \mathrm{~km}$ long and draws from a watershed of $45 \mathrm{~km}^{2}$. The brook has an average flow of $5 \mathrm{~cm} / \mathrm{s}$, cross channel width of $8.5 \mathrm{~m}$ and can be characterized as a free-stone creek with a traction load clast size-range of silt $(<0.1 \mathrm{~cm})$ to cobble $(20 \mathrm{~cm})$ size. The natural channel morphology of Mill Brook has been altered significantly resulting in loss of salmon and trout spawning habitat. In-stream structures (digger logs and deflectors) were installed in July and August 1995 in an effort to re-establish the original channel pattern of the river.

Research focused on a detailed examination of the impact on stream morphology of the in-stream structures. It was found that the ability of the in-stream structure to alter river bed morphology is dependent on the dimensions and orientation of the structure itself, the bed composition of the river (bedrock, freestone or sand) and flow velocity and depth. Stream bed monitoring stations were installed at three of the modification structures. Within one month of installation the development of a subtle thalweg was observed and sand and silt-sized sediment was absent from the bed load. These observations were made while the stream was at low stage indicating that further re-organization of the stream bed can be expected. These changes occurred during low water conditions indicating that the structures have the potential to transport larger substrate at higher rates. The effectiveness of in-stream structures is dependent on a detailed understanding of the system in which they are to be employed. The information collected in this study will serve to guide further remediation efforts. 